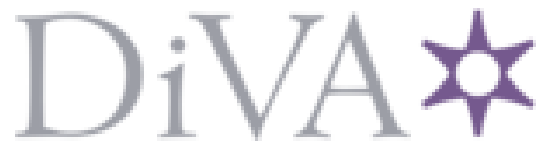

http://www.diva-portal.org

Preprint

This is the submitted version of a paper presented at ICQE 2021, Third International Conference on Quantitative Ethnograph, Virtual via Malibu, CA, USA, November 6-11, 2021.

Citation for the original published paper:

Schnaider, K., Schiavetto, S., Spikol, D. (2021)

Democracy and Social Inequalities in the Organization of Education during the COVID-19 Pandemic: The Case of Brazil and Sweden

In: Zörgö, S. (ed.), Advances in Quantitative Ethnography (pp. 301-319).

N.B. When citing this work, cite the original published paper.

Permanent link to this version:

http://urn.kb.se/resolve?urn=urn:nbn:se:umu:diva-189386 


\title{
Democracy and Social Inequalities in the Organization of Education during the COVID-19 Pandemic: The Case of Brazil and Sweden
}

\author{
Karoline Schnaider $^{1}$, Stefano Schiavetto ${ }^{2}$, Daniel Spikol ${ }^{3}$ \\ ${ }^{1}$ Umeå University, Umeå, Sweden \\ karoline.schnaider@umu.se \\ ${ }^{2}$ State University of Campinas, Campinas, Brazil \\ s072392@dac.unicamp.br \\ ${ }^{3}$ University of Copenhagen, Copenhagen, Denmark \\ dsedi.ku.dk
}

\begin{abstract}
Challenges that arise during a time of crisis, as the current COVID-19 pandemic, are a basis for recognizing how different governments handle the governance of units such as schools and issues related to democracy and social inequality. By paying attention to similar or contrasting issues in the political welfare states' characteristics and organization, the crisis's impact on different countries can be identified and can provide learning examples beyond the study's phenomena. Although Brazil and Sweden are historically and culturally diverse countries, they also share similarities in being politicized by global trends such as neoliberalism. The paper examines the two governments' discourses and how centralization, decentralization, and neoliberalism and the resulting shift to privatized public services can form a basis for understanding declines in democracy and social inequality in schooling in both countries. The following research question guides the work, how are democracy and social inequality expounded in Brazil's and Sweden's way of organizing education during the COVID-19 pandemic? To investigate how democracy and social inequality were expounded in Brazil's and Sweden's way of organizing education during the COVID-19 pandemic, we used a quantitative ethnographic approach to analyze the government's discourses. With quantitative ethnographic techniques we identified how the states organized discussions and actions to investigate and solve socio-educational issues related to democracy and how access to resources for education related to inequalities. The governmental intensity of keeping the economy functioning was observed to be influenced by the advance of neoliberalism in both countries. In organizing the education during the COVID-19 pandemic neoliberalism is pertaining to authoritarianism in Brazil and more culturally contingent actions related to the ethos - "openness" - in Sweden.
\end{abstract}

Keywords: Education, Democracy, Social Inequality, Organization, Quantitative Ethnography. 


\section{Introduction}

The crisis's impact on different countries can be identified by paying attention to similar or contrasting issues in the political welfare states' characteristics and organization. With various consequences, it provides learning examples beyond the study's phenomena. Although Brazil and Sweden are historically and culturally diverse countries, they also share similarities in being politicized by global trends such as neoliberalism. One topic playing a significant role worldwide has been the rise of neoliberalism by leaders such as Pinochet in Chile, Thatcher in the United Kingdom, and Guedes and Bolsonaro in Brazil, but also transpiring more unarticulated in welfare states such as Sweden [1]. A core of neoliberalism is privatization, although it is not excluding the state from cofinancing or the state's tasks in reducing social inequalities through, for instance, inclusive laws [1].

A neoliberalist authority accommodates fewer assistance policies [1,2] and has less interference even in fundamental areas such as education. It is occupied by private and for-profit entrepreneurship that can affect democracy and equality. Individual economic growth becomes the basic principle to a collective reduction of inequalities - an economization of politics and a depolitization of the economy - in which citizens sacrifice politicized citizenship in the belief that economic growth is sufficient for individual and collective well-being [2].

In this paper we look deeper into Brazil's and Sweden's way of organizing education during the COVID-19 pandemic. We examine the governments' discourses and how centralization, decentralization, and neoliberalism, and the resulting shift to privatized public services can form a basis for understanding the decline in democracy and social inequality in schooling in both countries. The following research question guides the work, how are democracy and social inequality expounded in Brazil's and Sweden's way of organizing education during the COVID-19 pandemic?

\section{Background}

The organization of the society in Brazil and Sweden is briefly sketched in this section. It is the footing for understanding how education got affected differently in the countries during the pandemic times. Brazil and Sweden share a similar governance structure where the state or federation is responsible for higher education institutions. In contrast, decentralized entities such as states (Brazil) and municipalities (Sweden) have responsibilities for secondary education and municipalities for the primary in Brazil. Through the ministry and Departments of Education, the governments coordinate incentives and policies between decentralized and other state institutions and civil society. 


\subsection{Democracy and Inequality in Education}

The states' centralized and decentralized coordination of schools in Brazil and Sweden is one of the pillars for democratic governance to overcome inequalities. According to Dahl [3], democracy can be attributed to the political regimes of the 20th century that institutionalized political equality as a fundamental requirement - the so-called polyarchies - permeating laws, policies, and the governance of schools. For the effectiveness of democracy, especially after the Second World War, public funding of primary and secondary education was observed. For instance, since the promulgation of the new Federal Constitution in 1988 in Brazil, which ended in a military dictatorship between 1964-1985, several governmental sectors and civil society representatives created democratic regulations to put the new Federal Constitution into effect. The last policy document related to education was completed in 2018 [4]. The Swedish Department of Education is basing its governance on laws and practices, continuously reviewed by state and society and applied mainly since the second half of the 20th century, which has been effective in enhancing democracy and reducing inequalities. Thus, the recent efforts made by the Brazilian government to improve social inequalities is a more modern democratic and creative historical moment, which was current in Sweden for more than half a century. Since the second half of the twentieth century, Sweden is a world reference in low social inequalities and high-quality education. At the same time, Brazil has figured worldwide between 2002 and 2015 as a reference in overcoming social disparities, with programs focused on amending the effects on education.

\subsection{Privatization and Neoliberalism}

Since democracy has not proven to be a stable accomplishment, rather it is an ongoing dynamic process between government and society and institutionalized laws do not always have guaranteed outcome for the benefit of citizens [3]. At the same time, one of the main threats to democracy is social inequality which is likely to generate segregation in access to essential resources and the population's spaces of power. Moreover, cultural discrimination, life reduced to material survival, political apathy, and less representation of social groups in government can favor the rise of authoritarian and populistic political figures. According to Brown [2], such changes in social inequality ideologically relates to a strive for individual economic development as the primary driver of equality that simultaneously reduces political citizenship to economization. Resulting in political apathy, sacrificial citizenship means that the "citizen is bound to the sole and supervening value of economic growth and thus may be sacrificed to capital's needs, vicissitudes and inequalities at their job, in their nation or post-national constellation." [2, p.9].

Neoliberalism has been observed in the scientific literature for four decades now as growing privatization, deregulation, and states' diminished role in the economy and programs for equality, raising questions about its possible impacts on democracy and inequalities [2]. Political equality is maintained through, e.g., education, but under new meta-stabilities between government and society, which provide the students with mainly juridical equality in the world of work under sacrificial citizenship. Neoliberal 
changes have been observed in Brazil and Sweden in education, accelerated by the privatization and for-profit trends [5-9].

Since the election of a neoliberal president in 2018, Brazil underwent profound changes. Privatization of public services and strict measures to cut welfare investments were in progress and even accentuated during the COVID-19 pandemic [10]. For instance, a reduction by $25 \%$ of the budget for academic research was a change in education due to this. Subsequently, a reduction of all the universities' budgets was made [11, 12] to analyze the quality of the programs to prepare professionals for the job market [13] and to generate "economic growth" by producing more doctors, nurses, dentists, and engineers while limiting "sociologists, anthropologists, and philosophers" [14].

Burström [15] addressed the accelerated privatization and the effects on democracy and equality in Sweden. For instance, the Swedish public service increasingly occupied for-profit companies between the early 1990s and 2016 (from $2 \%$ to $19 \%$, [16]). According to Diderichsen [17], the changes have made Sweden more comparable with the United Kingdom than with the other Nordic countries. Recently, the same trends were seen in elderly care, where $25 \%$ of the maintenance got dominated by two large companies [18]. Dahlgren [19] showed that market-oriented health care reforms in Sweden reduced efficiency, priority for patients, fewer opportunities for quality control of services, resulting in an expansion of social inequalities that seemed to undermine the power of the democratic institutions. A recent study confirmed that during the COVID19 pandemic, privatization appeared to be one problem alongside intensive work by professionals and the absence of supportive leadership, resulting in high mortality [20].

In summary, the paper takes the stance that aspects of democracy in both Brazil and Sweden can be seen to under threat by the advance of neoliberalism, based on an observation of how each government dealt with remote education during the COVID-19 pandemic and its impacts on inequalities. In common between Brazil and Sweden, this threat is expressed by a relationship between two factors: the minimization of citizen participation in public power, which is fundamental for defining a state as democratic [3], and the advance in the privatization of public services, in a neoliberal ethics [1,2]. Despite sharing this neoliberal minimization of citizen participation in democracy, Brazil and Sweden exemplify two trends of contemporary neoliberal heterogeneity. While the South American country expresses an authoritarianism in the conduct of neoliberal reforms, by an elected party that centralizes the decision-making, the Nordic country expresses a broad decentralization of the decision-making process, in a culture more tolerant of a "sacrificial citizenship" [1,2]. The paper explores this shift in the cases of the two countries during the COVID-19 pandemic with a focus on education.

\section{Data Processing}

To investigate the two governments' response and the effect on democracy and education, methods of quantitative ethnography was used to analyze the governments' official communications. The benefit of these quantitative ethnographic techniques allowed us throughout the different data management steps to process and analyze a large amount 
of data [21]. We discuss the choice and collection of the data, the initial segmentation, the code generation, the second data segmentation, and the data analysis in this section.

\subsection{Data Retrieval and First Segmentation}

Data communicated by the Brazilian and Swedish governments were observed during the years 2020-2021 when the COVID-19 pandemic had advanced worldwide. The content of the governments' discourses was relevant to explore because they were considered to convey information about the changes in the organization of education related to democracy and social inequality. Manual searches were performed on the respective countries' web pages, www.mec.gov.br (Brazil), and the website www.regeringen.se (Sweden).

Several selection criteria were operated to obtain a valid collection of data for the paper (Table 1). A consensus amongst the researchers was made by discussing the categories available in the filer function on respective governments' webpages. After testing different search options, similar settings were made to match the information from the Brazilian and the Swedish website and make it comparable. General inclusion and exclusion criteria were defined as connected to the purpose of the study. Coronavirus and Corona were deemed to be the aptest search terms to get results of each government's actions related to the COVID-19 pandemic. The Content was not activated and excluded searches of specific media types such as articles, information material, reports, etc., as different data sources were essential to get a broad representation of information. Basic education and Child-and youth education were used respectively to get search results related to the specific area under study - the governments' measures and incentives associated with the organization of education. Similarly, the Ministers (Brazil) and the Department (Sweden) were used to filer the information communicated by the governmental institutions related to education in each country. Because the phase when the COVID-19 pandemic began to bear on the organization of schools was similar in both countries, the Period delimiting the searches was set between March 1, 2020, to the present time, April 22, 2021. The information obtained contained the statements of the Ministers of Education, memoranda, amendments to the law, etcetera.

Table 1. Search settings.

\begin{tabular}{l|ll} 
Search settings: & Brazil: & Sweden: \\
\hline Search term: & Coronavirus & Corona \\
Content: & - & - \\
Area: & Basic education & Child- and youth education \\
Ministers: & Ministry of Education & - \\
Department: & & Education \\
Period: & March 1, 2020- April & March 1, 2020- April 22, \\
& 22,2021 & 2021 \\
\hline
\end{tabular}


Text data from the two web pages were manually downloaded and imported into separate documents. Respective native languages were converted into English with online translation tools, followed by a manual screening of the texts to correct translation errors and clean the files by removing irrelevant data. The first round of segmentation included separating the texts into lines or clusters of lines depending on how the content addressed or framed different social inequality and democracy aspects. All text data was transferred to a spreadsheet before the second segmentation and code generation and resulted in 3766 rows for the entire dataset.

\subsection{Code Generation, Second Segmentation, and Coding}

The initial stage of code generation included hypothesis modeling. A hypothesis is a proposed explanation of the studied phenomena, a conceptual statement yet untested, formulated into a prediction that quantifies defined variables [22]. The hypothesis that guided the data processing was based on social inequality and democracy in education and predicted that some of their components would occur more often in Brazil and Sweden.

Repeated procedures of top-down and bottom-up moderation were undertaken to define the variables (the codes) by identifying values (codewords) to determine the codes [23]. Social inequality and democracy formed overarching classes and were deductively guiding the top-down processes in understanding the data. It included social moderation [24] and manual screening of the first 200-word frequency counts made in NVivo 12, ranging in occurrence from 1600 ("education") to 50 ("way"). A manual search of the dataset followed this step to define the potential codewords. Data was additionally screened numerous times in the bottom-up moderation to refine the categories by sorting additional codewords under each category and grouping them under a suitable label. Eight codes were defined during these processes (Table 2).

Table 2. Codebook.

\begin{tabular}{|c|c|c|c|c|c|c|c|}
\hline Category: & $\begin{array}{l}\text { Final } \\
\text { codes: }\end{array}$ & Codewords: & Definition: & Example: & HC1/AC 1 & HI1/HC ${ }^{2}$ : & $\mathrm{HC} 2 / \mathrm{AC}^{3}:$ \\
\hline & $\begin{array}{l}\text { Support } \\
\text { and oppor- } \\
\text { tunities }\end{array}$ & $\begin{array}{l}\text { School, } \\
\text { Transport, } \\
\text { Food, Meal, } \\
\text { Nutrition, } \\
\text { Principal, } \\
\text { Premise, } \\
\text { Higher educa- } \\
\text { tion, Support, } \\
\text { Opportunity, } \\
\text { Opportunities, } \\
\text { Condition }\end{array}$ & $\begin{array}{l}\text { Discourses around how to } \\
\text { support the teaching or- } \\
\text { ganization to maintain } \\
\text { school attendance, man- } \\
\text { date to principals, provid- } \\
\text { ing transportation, food, } \\
\text { technologies, postponing } \\
\text { exams to access higher } \\
\text { education. }\end{array}$ & $\begin{array}{l}\text { "This shall also apply } \\
\text { to study start support } \\
\text { for certain unemployed } \\
\text { people who need to en- } \\
\text { roll in a basic or upper } \\
\text { secondary education. } \\
\text { High school students' } \\
\text { student aid will con- } \\
\text { tinue to be paid out." }\end{array}$ & $.99 * *$ & $.99^{* *}$ & $.99 * *$ \\
\hline
\end{tabular}

\footnotetext{
${ }^{1}$ Kappa $(\mathrm{K}>.9)$ - level of agreement between the first human rater and the automated classifier in nCoder

${ }^{2} \mathrm{Kappa}(\mathrm{K}>9)$ - level of agreement between the first and second human raters in $\mathrm{nCoder}$

${ }^{3} \mathrm{Kappa}(\mathrm{K}>9)$ - level of agreement between the second human rater and the automated classifier in nCoder
} 


\begin{tabular}{|c|c|c|c|c|c|c|c|}
\hline \multirow[t]{2}{*}{ Inequality: } & $\begin{array}{l}\text { Organiza- } \\
\text { tion and } \\
\text { methods }\end{array}$ & $\begin{array}{l}\text { Face-to-face, } \\
\text { Online, Dis- } \\
\text { tance, Remot, } \\
\text { Teach, Adapt, } \\
\text { Technolog, } \\
\text { Technique, } \\
\text { Special } \\
\text { school, Spe- } \\
\text { cial education, } \\
\text { Special need, } \\
\text { Subject }\end{array}$ & $\begin{array}{l}\text { Discourse around the } \\
\text { teaching organization, } \\
\text { closing of schools, reo- } \\
\text { pening of schools, dis- } \\
\text { tance, face-to-face and } \\
\text { hybrid education, technol- } \\
\text { ogies, and techniques. }\end{array}$ & $\begin{array}{l}\text { "Distance learning } \\
\text { means that teaching is } \\
\text { interactive and takes } \\
\text { place in real time by } \\
\text { using information and } \\
\text { communication tech- } \\
\text { nology." }\end{array}$ & $.99 * *$ & $.91^{*}$ & $.91^{*}$ \\
\hline & Learning & $\begin{array}{l}\text { Learn, Study, } \\
\text { Studies, De- } \\
\text { velopment, } \\
\text { Activit, } \\
\text { Knowledge, } \\
\text { Qualit, Course }\end{array}$ & $\begin{array}{l}\text { Discourses on how to pre- } \\
\text { vent the decline in quality } \\
\text { of learning for students } \\
\text { involving study methods, } \\
\text { learning strategies and } \\
\text { guidelines. }\end{array}$ & $\begin{array}{l}\text { "The purpose is to in- } \\
\text { crease the state subsidy } \\
\text { that principals can ap- } \\
\text { ply for to offer law } \\
\text { school to students who } \\
\text { have not reached or } \\
\text { risk not reaching the } \\
\text { knowledge require- } \\
\text { ments for the grade E." }\end{array}$ & $.97 * *$ & $.96^{*}$ & $.99 * *$ \\
\hline Category: & $\begin{array}{l}\text { Final } \\
\text { codes: }\end{array}$ & Codewords: & Definition: & Example: & HC1/AC: & HI1/HC: & HC2/AC: \\
\hline \multirow{5}{*}{$\begin{array}{l}\text { Democ- } \\
\text { racy: }\end{array}$} & Investments & $\begin{array}{l}\text { Million, Fund, } \\
\text { Resource, } \\
\text { Aid, Invest- } \\
\text { ment }\end{array}$ & $\begin{array}{l}\text { Discourses around the re- } \\
\text { allocation of ordinary re- } \\
\text { sources and how to apply } \\
\text { extraordinary resources, } \\
\text { related to the reorganiza- } \\
\text { tion of education during } \\
\text { the pandemic. }\end{array}$ & $\begin{array}{l}\text { "In terms of resources, } \\
\text { SEK } 944 \text { million will } \\
\text { be added in } 2020 \text { and } \\
\text { SEK } 1,174 \text { million in } \\
2021, \text { including study } \\
\text { funds for these invest- } \\
\text { ments." }\end{array}$ & $.97 * *$ & $.91 *$ & $.94 *$ \\
\hline & $\begin{array}{l}\text { School sys- } \\
\text { tem man- } \\
\text { agement }\end{array}$ & $\begin{array}{l}\text { Compulsory, } \\
\text { Preschool, } \\
\text { Right, Univer- } \\
\text { sity, Universi- } \\
\text { ties, Primary, } \\
\text { Secondary, } \\
\text { Basic educa- } \\
\text { tion, Assess }\end{array}$ & $\begin{array}{l}\text { Discourses around the ex- } \\
\text { plorations of the impacts } \\
\text { of the pandemic on the } \\
\text { teaching units (schools } \\
\text { and universities) and how } \\
\text { to solve them. }\end{array}$ & $\begin{array}{l}\text { "Basic education - The } \\
\text { MEC, the National } \\
\text { Council of Education } \\
\text { Secretaries (Consed) } \\
\text { and the National Union } \\
\text { of Municipal Educa- } \\
\text { tion Directors (Un- } \\
\text { dime) are analyzing the } \\
\text { possibility of making } \\
\text { the fulfillment of the } \\
200 \text { school days more } \\
\text { flexible, as provided } \\
\text { for in the Law of } \\
\text { Guidelines and Bases } \\
\text { (LDB)and study the } \\
\text { maximum workload } \\
\text { that can be offered in } \\
\text { distance mode." }\end{array}$ & $.99 * *$ & $.99 * *$ & $.99^{*}$ \\
\hline & $\begin{array}{l}\text { COVID-19 } \\
\text { spread } \\
\text { control }\end{array}$ & $\begin{array}{l}\text { Spread, Infec- } \\
\text { tion, Recom- } \\
\text { mendation, } \\
\text { Measure, } \\
\text { Consequence }\end{array}$ & $\begin{array}{l}\text { Discourses on how to } \\
\text { contain the spread of the } \\
\text { new corona virus in edu- } \\
\text { cational environments. }\end{array}$ & $\begin{array}{l}\text { "The spread of infec- } \\
\text { tion needs to be re- } \\
\text { duced to limit the ef- } \\
\text { fects on human health } \\
\text { and economic conse- } \\
\text { quences." }\end{array}$ & $.99 * *$ & $.99 * *$ & $.99 *$ \\
\hline & $\begin{array}{l}\text { Gover- } \\
\text { nance and } \\
\text { society }\end{array}$ & $\begin{array}{l}\text { Ministry, } \\
\text { Minister, Inep, } \\
\text { National } \\
\text { agency, De- } \\
\text { cide, Neces- } \\
\text { sary, Program, } \\
\text { Close, Reo- } \\
\text { pen, State, } \\
\text { Municipal, } \\
\text { Federal, Re- } \\
\text { turn, Partici- } \\
\text { pat, Extraordi- } \\
\text { nary, Strength }\end{array}$ & $\begin{array}{l}\text { Discourses around the in- } \\
\text { volvement of the society } \\
\text { in the investigation and } \\
\text { solution of the pandemic's } \\
\text { impact in primary and } \\
\text { secondary education. }\end{array}$ & $\begin{array}{l}\text { "For the representative } \\
\text { of Unicef, this process } \\
\text { of reopening schools } \\
\text { will be the biggest } \\
\text { challenge that new mu- } \\
\text { nicipal leaders will } \\
\text { face in 2021." }\end{array}$ & $.99 * *$ & $.99 * *$ & $.99 * *$ \\
\hline & $\begin{array}{l}\text { Laws ap- } \\
\text { plication } \\
\text { and new } \\
\text { regulations }\end{array}$ & $\begin{array}{l}\text { Enem, Educa- } \\
\text { tion act, Regu- } \\
\text { lation, Provi- } \\
\text { sion, pnae, } \\
\text { section, fnde, } \\
\text { ordinance, ad- } \\
\text { justment, } \\
\text { amendment, } \\
\text { law }\end{array}$ & $\begin{array}{l}\text { Discourses on laws re- } \\
\text { garding the reorganization } \\
\text { of education. }\end{array}$ & $\begin{array}{l}\text { "Through an amend- } \\
\text { ment to the ordinance, } \\
\text { upper secondary } \\
\text { schools can now, under } \\
\text { certain conditions, } \\
\text { combine local educa- } \\
\text { tion with certain dis- } \\
\text { tance or distance edu- } \\
\text { cation." }\end{array}$ & $.99 * *$ & $.97 *$ & $.97^{*}$ \\
\hline
\end{tabular}

$*$ rho $\leq .05, * *$ rho $<.01$ 
Before coding, a second source- and delimiter-based segmentation was carried out to prepare the data for analysis with $\mathrm{ENA}^{4}$ [25]. Source-based segmentation included grouping the lines in the text data by adding columns in the spreadsheet with meaningful contextual information that could help determine the social inequality and democracy categories and from which ENA was operating (used as conversations). Metadata was added as a significant source for segmentation, in which the lines were used as "utterances". Time was an essential factor as the different time periods during the COVID-19 rendered different kinds of information. Two columns for month and year were therefore added as a delimiter-based segmentation [26].

Coding was performed using the software $\operatorname{Coder}^{5}$ [27] to assess inter-rater reliability (IRR) and agreement between raters and validity to the conceptualization of the codes. nCoder was used by two human raters $(\mathrm{H} 1 / \mathrm{H} 2)$ and an automated classifier (AC) that examined approximately 10 percent of the total number of coded expressions through the eight codes (Table 3). The agreement level between the raters on all the codes resulted in a Cohen's kappa of $>.90$ (see codebook, Table 2).

Table 3. Descriptive statistics of datasets.

\begin{tabular}{llll}
$\begin{array}{l}\text { Country } \\
\text { (units): }\end{array}$ & $\begin{array}{l}\text { \# unique } \\
\text { datasets }\end{array}$ & hits & $\begin{array}{l}\# \text { coded lines } \\
(\boldsymbol{N}=\mathbf{3 7 6 6})\end{array}$ \\
\hline Brazil & 1 & 67 & 1553 \\
Sweden & 1 & 99 & 2212 \\
\hline
\end{tabular}

\subsection{Data Analysis}

The coded data was used with the Epistemic Network Analysis (ENA) Web Tool v1.7.0 (Marquart et al., 2018) to visualize networks of how social inequality and democracy occurred in Brazil's and Sweden's governmental discourses around the organization of education during the pandemic year. ENA uses stanzas to connect items in the data and is modeled with stanza windows based on the chosen conversation for each unit of analysis (Brazil and Sweden). A moving stanza window of size 10 was set in ENA after testing different alternatives with similar results due to the uncertainty in codewords between the rows. ENA visualizes centroids (boxes with plotted points) that indicate the units' means. Each unit connection is also modeled in ENA weighted networks positioned in the projection space enabling interpretation of the $\mathrm{x}$ and $\mathrm{y}$-axes dimensions and understanding the frequency of co-occurrence between codes [28].

\footnotetext{
${ }^{4}$ https://www.epistemicnetwork.org/

${ }^{5} \mathrm{https}: / /$ www.n-coder.org/
} 


\section{Result and Analysis}

The ENA network connections were initially analyzed visually - the units' (centroids) position in the $x-y$ projection space to obtain a general perspective on the differences between the Brazilian and Swedish discourse on social inequality and democracy in the organization of education during the COVID-19 pandemic. The next step included an exposition of the ties between the nodes (codes). The thickness of the lines and the size of the codes were associated and addressed and linked to their definitions and codewords. By integrating stanzas from the text data to exemplify the meaning of the connections, the interpretative loop was closed [21].

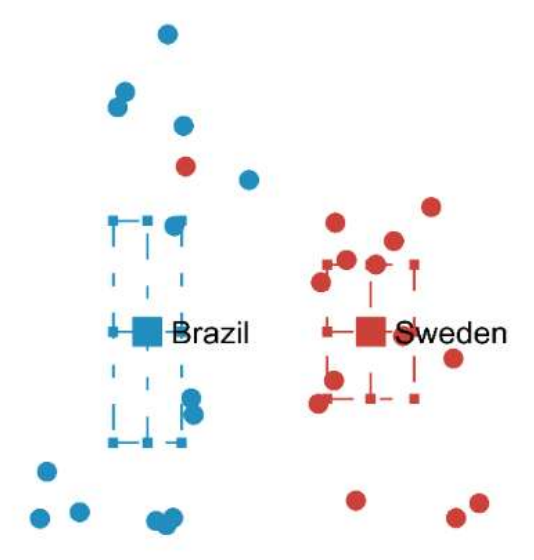

Fig. 1. Mean of the plotted points for each country.

The centroids (boxes) with plotted points (Figure 1) visually indicate that the Brazilian discourse is statistically significantly different from the Swedish discourse. A MannWhitney test statistically reinforced that observation on the X-axis (Table 5). The model had co-registration correlations of .95 (Pearson) and .94 (Spearman) for the first dimension and co-registration correlations of .98 (Pearson) and .98 (Spearman) for the second. These measures indicate that there is strong goodness of fit between the visualization and the original model.

Table 4. Mann-Whitney test statistics on differences between Brazil and Sweden.

\begin{tabular}{lllll} 
Countries & Axis & Median (N) & P-value* $^{*}$ & R (effect size) \\
\hline Brazil vs. Sweden & $\mathrm{X}$ & $\mathrm{Mdn}=.79$ & $\mathrm{p}=.001$ & $\mathrm{r}=.97$ \\
\hline \multicolumn{2}{r}{ *alpha level $<05$} & &
\end{tabular}

*alpha level $<.05$ 
The subtraction network (Figure 2) suggests that Brazil's position in the left dimension on the $\mathrm{x}$-axis relates it more firmly to democracy in the democracy-inequality continuum. In contrast, Sweden's situation on the right side relates it more firmly to the discourse around inequality. In the y-axis dimension, Brazil's communication is oriented relatively evenly towards how the state-organized discussions and actions to investigate and solve socio-educational issues to strengthen learning (Learning) by governing (Governance and society) with laws and regulations (Laws application and new regulations), and investments (Investments). Sweden's positioning in the y-axis dimension hints at differentiating the access to resources to support (Support and opportunities) and organize (Organization and methods) the education to benefit different groups. The following quotes can illustrate these observations: Brazil - "The National Education Development Fund (FNDE), linked to the Ministry of Education (MEC), anticipated the transfer of R \$ 67.9 million, the amount of the fourth instalment of the National School Transport Support Program (PNATE), scheduled for the end of the month." (ID: 2559) Sweden - "As long as teaching is provided, for example through distance learning, student support in the form of study aid, study grants and study start support will continue to be provided as usual." (ID: 6).

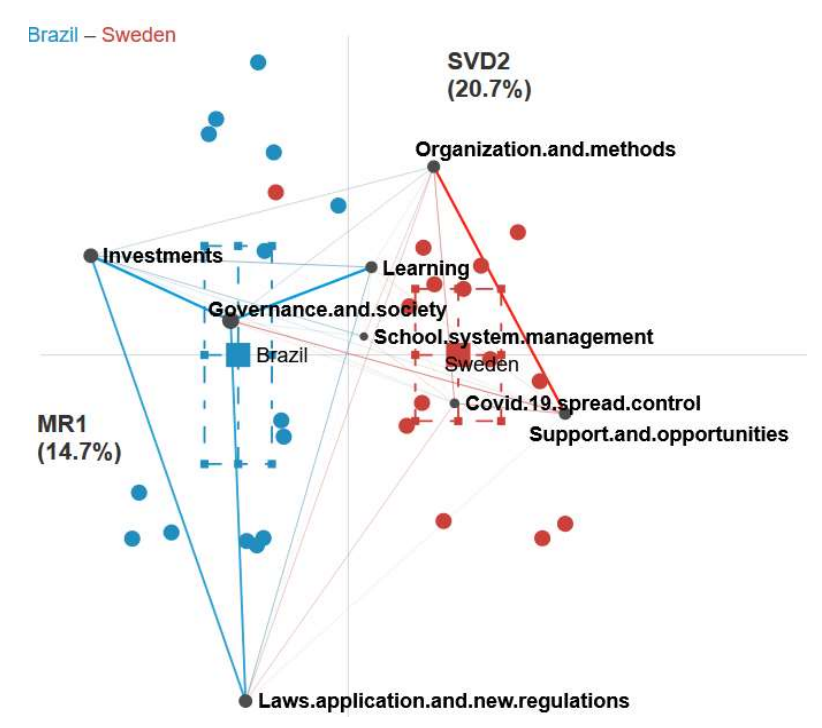

Fig. 2. Subtraction network modeling comparison between Brazil and Sweden.

\subsection{Analysis of the Countries}

This section describes the close-up perspective on Brazil's and Sweden's discourses on democracy and inequality in education identified in the comparison made in the previous paragraph. 


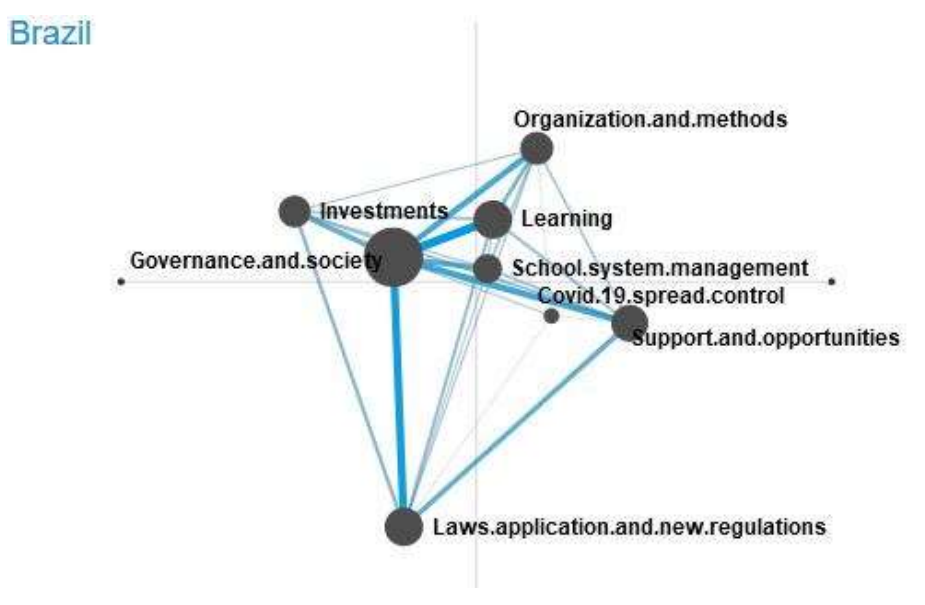

Fig. 3. Network modeling democracy and inequality in education related to Brazil.

Brazil. The network in Figure 3 signals a complex engagement by the Brazilian government in maintaining democracy in the organization of education during the corona crisis. There are some strong relationships between the codes in the network. For instance, the Ministry of Education increased its efforts to establish programs by monitoring the impacts of the pandemic and by forecasting the forthcoming steps on a federal and municipal level (Governance and Society) that lead to the adjustments of regulations and amendment of educational laws (Laws Application and New Regulations). These actions were taken to prevent the decline in the quality of learning in primary and secondary schools (Learning). In addition, governmental efforts (Governance and Society) directly impacted the organization of teaching and learning in schools, such as closing schools and transitioning to online modes, adopting new methods, technologies, and techniques (Organization and Methods). How the readjustments could be catered for and support the continuation of teaching and school attendance by allocating and differentiate the resources food, hygiene, and distribution of teaching managed on a local level by principals (Support and opportunities) was also observed. The following quote can exemplify these observations: The course is aimed at teachers, pedagogical coordinators, school principals, and assistants, all from the last year of pre-school and the first two years of elementary school and is also useful for managers of educational networks and all interested civil society, that is, parents and guardians, for example, who are interested in collaborating with their children's literacy, can also access content available entirely online and free of charge, and practice with the little ones" (ID: 2855). 


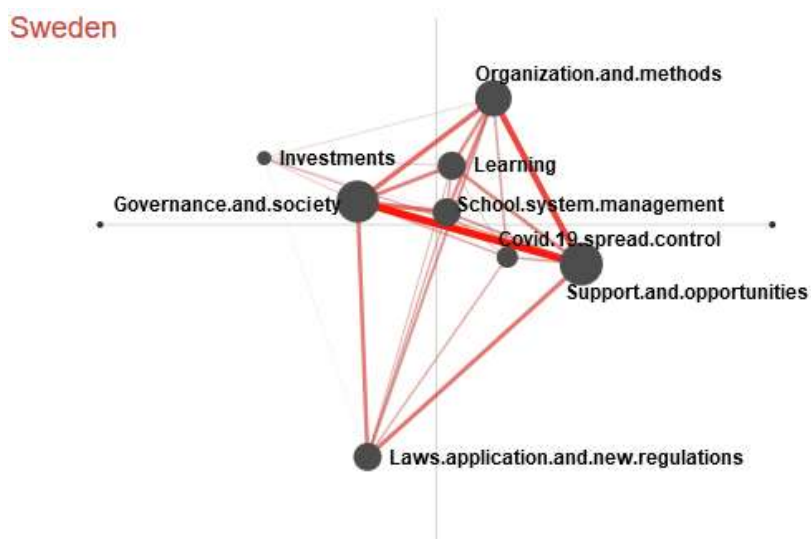

Fig. 4. Network modeling democracy and inequality in education related to Sweden.

Sweden. The connections in Figure 4 suggest that the Swedish government was managing the effect of the corona crisis on education that is different from how the Brazilian government acted. There are some strong relationships between the codes in the network related to their discourses. First, the network connections propose that governmental agencies and societal entities investigated issues and proposed solutions (Governance and Society) and necessary measures, e.g., curriculum changes and providing access to resources, while handling the extraordinary events in the time of crisis to maintain education (Support and Opportunities). The first decision to close secondary schools while still maintenance open primary schools, which respectively required the elaboration of methods for remote and distance education (Organization and Methods) and the adaptation of the school organization to comply with rules of social distance while sustaining the rights for education (School System Management). These measures were constantly expressed as anchored in the educational legislation already in force, emphasizing the Education Act (2010: 800) (Law Application and New Regulations). The concern with avoiding a drop in the quality of teaching (Learning) is expressed in all these investigations and actions. However, the funds for dealing with them are not salient in the discourses (Investments). The quote illustrates these observations: "Throughout the pandemic, the Ministry of Education has consulted with experts, educational actors, responsible authorities and organizations, representatives of school principals, employee organizations and student and student organizations to gain knowledge about how the virus has affected the activities and identify what needs exist" (ID: 686).

\section{Discussion}

This study addresses how democracy and social inequality were expounded in Brazil's and Sweden's ways of organizing education during the COVID-19 pandemic salient in the countries' discourses. By quantitative ethnographic techniques [21], we focused on how the two states organized discussions and actions to investigate and solve socio- 
educational issues related to democracy and how access to resources for education related to social inequalities. In the following section, we present the implication of these findings.

Democratization is closely associated with states that operate reforms to extend the population's right to participate in government decision-making. It is a movement to minimize the privileges of small groups and is observed worldwide, especially in the 20 th and 21 st centuries [3]. In the democratization movement, formal education has been characterized by a politicization of life, widely known as active citizenship. This concept and its relation to education has been discussed in the recent academic and political debate, from classical Greek (cf. Hannah Arendt, [29]), liberal (cf. Bobbio, [30]), to even Marxist legacies (cf. Gramsci, [31]; Saviani [32]). An education institutionalized by the state, primarily public or private, as seen in both Brazil and Sweden, is committed to the effectiveness of democracy and the reduction of historical, social inequalities. Although democracy and social inequality are shared premises between the countries, there are significant differences in how Brazil and Sweden framed their discourses around education during the last year. Brazil's Ministry of Education (MEC) engaged in discussions and actions more related to democracy. At the same time, the Swedish Department of Education's (SDE) debates related more to social inequality in the democracy-inequality continuum. While the Brazilian MEC centralized its decision-making, the Swedish SDE mediated between health authorities and schools for principals to optimize their decisions on a decentralized level. These observations are the pillars for further analysis of Brazil's and Sweden's actions and engagement in supporting education. Both countries focused on supporting the educational system, which can be related to the countries ethos in observing human rights.

\subsection{Wielding Democracy through Centralization and Decentralization}

The Brazilian government's centralization can be observed in the country since Social Liberal Party's victory in 2018 [34]. During the COVID-19 pandemic, the centralization showed traces of authoritarianism when the Ministry of Education avoided complying with democratic prerogatives. The discourses emphasize school governance by laws and regulations and is an effect of authoritarianism. The discourses reveal a topdown model that reduced decision-making according to local needs and with a direct impact on education. For instance, the MEC's Minister Abraham Weintraub publicly minimized the pandemic's seriousness and protested mayors' and governors' decisions to close schools [35]. On the other hand, national universities wanted to close schools and continue with remote education to contain social inequalities in education [36-39]. Instead of bringing together governors, mayors, health authorities, and education-related institutions for decision-making on joint actions to minimize the impacts of the pandemic on education, MEC insisted on taking its path and asked the population to pressure governors and mayors to regain what he called "common sense" and reopen schools [40]. For example, MEC provided hygiene kits to schools throughout the year even when they were closed to provide good sanitary conditions and reactivate face-toface education. Hence, Brazilian centralization is expressed through the MEC's decision-making taken in isolation from other educational institutions, states, and municipal governments. It contradicts the inclusive character given to local institutions for investigating local needs and participating in decision-making, which is a hallmark of the 
country's re-democratization [41, 42]. The centralized governance affected democracy because it ended up in authoritarian instead of more inclusive and decentralized practices to solve various issues. The authoritarianism also resulted in social inequalities because social actors were silenced and imprecise federal funding to support local needs was delivered. Conclusively, the year 2020 ended with a decline in the local entities' participation in decision-making and simultaneously a rise in social inequalities in education [43].

Contrary to the Brazilian centralization, the Swedish discourse related firmly to its decentralized democratic structure. During the COVID-19 pandemic, the Swedish people's historic high trust in the state made newly adopted decisions approved quickly on a local level. According to Nygren and Olofsson [44], Swedish culture shows specific ethopolitics, understood as governing of conduct and individual responsibilization where the state is a mediator between specialists to provide recommendations for personal choices. For instance, the Swedish government acted between the SDE, The Swedish Public Health Agency, municipalities, and school principals. These actions were observed in the government's discourses that dealt with maintaining equal education with resources and re-organization of local entities. The authorities' executive power made the National Health Agency's recommendation to, e.g., keep schools open, principals occupied with organizing hybrid teaching in face-to-face, distance, and remote modes. At the same time, local entities were complying with the " [p]ersonal responsibility rather than legislation [...] to take measures so that employees could keep social distancing" [17].

\section{$5.2 \quad$ Neoliberalism}

Over the past 40 years, most democratic countries around the world have operated neoliberal policies. From a neo-Marxist perspective, neoliberal rationality is based on a redefinition of the state as a regulator of social life by reducing welfare state policies. For instance, deregulation of capital and organized labor, public services' privatization, and for-profit, and favorable financial environments for foreign investors to expand multinational companies are a few examples. The Foucauldian perspective views neoliberal rationality as re-signifying the government, the subjectivities, and subjects. Subjectivities and subjects are active in capital entrepreneurship and competitive environments that demand the state to be a guarantor (and not a regulator) of the new subjects' and subjectivities' demands. Inspired by these theoretical perspectives, Wendy Brown $[1,2]$ investigated the neoliberal rationality and how the reduction and resignification of the primary democratization agent [3], the state, has impacted on democracy and social inequalities. Drawing on these perspectives, some aspects are fascinating to illuminate the results of this article. First, Brown [1] observes that resignification moves the states' actions towards conservative morality. It is a reduction and a cultural revision of the classical liberal concept of freedom (i.e., the satisfaction of personal needs) diminished to "unregulated personal license", which has been present in historically privileged groups' discourses and actions and increased their role in social movements and political parties worldwide. Connections between neoliberalism and increased conservative morality, associated with political right-populist and extreme parties expanding their presence on the political scene, is salient in Brazil and Sweden's governance. Second, Brown also notes that the reduction and resignification impact citizens' review 
of their citizenship, sacrificing political participation in pursuing individual economic growth because it is the primary condition for empowerment and social development. Both principles are setbacks in democratization [3]. Although these two tenets can be observed in Brazil and Sweden. The first principle around conservative morality is emphasized in Brazil's discourse around education. In contrast, sacrificial citizenship is used to understand the Swedish governments' actions.

The presidential election in 2018 explicitly advanced the neoliberal ideology, and privatizations of public services took off along with strict measures to cut investments on welfare policies, which got even more accentuated during this time [45]. The discourses conveyed by the Brazilian government and actors such as Weintraub (MEC), Paulo Guedes (Minister of Economy), Damares Alves (Minister of Culture), and Jair Bolsonaro (President of the Republic) indicate a strong interest in restructuring national education to eliminate what they call "cultural marxism." [46] This tendency is considered an ideology that dominated Brazilian and foreign schools and universities and international organizations such as the UN, depriving traditional moral values. For instance, teaching around sex education, LGBTQIA+, feminism, human rights, and the politicization of life are examples of what they call distortions of traditional values during the last decades.

The Brazilian government's restructuring of national education is also a project of privatization. It reduced the state's interference in the economy and society. One privatization measure advocated during this time was home-schooling - as a freedom for the family to offer education [46]. Other, voucher policies - as a freedom for low-income families to enroll students in private for-profit or confessional schools [47]. However, these neoliberal projects suffered widespread common and congressional resistance. Later, MEC protested against mayors' and governors' decision to close schools while allowing for the Ministry of Economy to implement activities necessary for individual growth to be promoted and to avoid social inequalities [40]. In summary, there is a centralization of political power by the federal government in Brazil, which conflicts with the country's recent democratization [3] and leads to authoritarianism. Privatization of education associated with a conservative morality, a depolitization of citizenship, and a conception of personal economic growth became means for reducing social inequalities [2] and can be observed in the federal government's actions during the pandemic to change education.

Brown's perspective is helpful to identify how the decentralized governance in Sweden relates to the Swedish ethos and how that got salient in the government's discourse on education during the COVID-19 pandemic. In the early 1980s, Sweden began adopting neoliberal policies promoted by center-right parties. Deregulation and decentralization, and slowly privatized education were some of the outcomes. The reforms resulted in transferred responsibilities from the government to municipalities and principals for governance and financing of education [7]. These measures were necessary to improve education and social justice in schools since deregulated and decentralized projects and financial resources could better meet local demands [8]. The other Nordic countries also adopted these changes, but while they authorized privatization and forprofit entrepreneurship to a limited extent, Sweden "has been eager to incorporate neoliberal ideas" [7, p. 128]. According to Nygren and Olofsson [44], the Swedish culture shows a specific ethopolitics in this way, where governing of conduct and individual responsibilization is strong. The state is a mediator between specialists and authorities 
and provides recommendations for personal choice, which signifies Swedes' high trust in the state and its distinction to other countries. According to Strang, ethopolitics is also marked by financial values being salient in the public debate and "that a functioning economy is a prerequisite for people's well-being and health." [48] Thus, individual economic growth is viewed as a key to a collective reduction of inequalities, which made the governments decide not to lockdown during the COVID-19 to keep the economy running and generate social advances. Alongside the absence of supervision and supportive leadership, neoliberalist tendencies are one factor that influenced the government's discourse around social inequality during the pandemic, mainly focused on local measures to support schooling. The decentralized governance reduced equal schooling for all by providing fewer opportunities for quality control of services which undermined the democratic institutions' power to secure social equality in areas such as education, instead occupied by private and for-profit entrepreneurship. Consequently, the neoliberalized ethos with high trust in the state resulted in a transfer of responsibility for well-being from the critical and politically active citizen to the successful individual citizen focused on economic growth. In summary, Sweden's culture is more tolerant to neoliberal advances and sacrificial citizenship and decision-making distributed under a functioning economy, which weakens citizens' abilities to be critical to the government's decisions [48].

\section{Conclusions}

Understanding the Brazilian and Swedish organizations of education during the pandemic is essential since both countries can influence other parts of the world. The crisis's impact on different countries was identified by paying attention to similar or contrasting issues in the political welfare states' characteristics and organization. This article specifically observed the entities responsible for the democratic and citizen formation of the population: the Ministry of Education in Brazil and the Department of Education in Sweden. The following research question guided exploring the governments' discourses: how are democracy and social inequality expounded in Brazil's and Sweden's way of organizing education during the COVID-19 pandemic?

Two underlying causes affected democracy and social inequalities in Brazil and Sweden's way of organizing education during the COVID-19 pandemic. First, Brazil's centralized government instituted programs for teaching and learning. In contrast, the Swedish decentralized government offered support to principals to adopt local measures. Accelerated privatization of education was identified as a similarity in both countries. The advance of neoliberalism influences the governments' actions to keep the economy functioning during the COVID-19 pandemic, where individual economic growth is the main driver to overcome social inequalities, which affected education during this period. Neoliberalism was observed in the authoritarian actions taken by the current Brazilian government and more culturally contingent actions related to the openness of the Swedish ethos. For instance, the new government in Brazil committed to reducing welfare policies on a central level, with education being an essential entity for changes. Conservative political parties and social groups embraced neoliberalism, which marked the redefinition of the classical liberal freedom into conservative morality - a satisfaction of personal needs for neoliberal freedom and unregulated personal 
license - which in many cases justified oppression [1]. The Swedish ethos - governing of conduct and individual responsibilization - resulted in an increased shift towards an economization of citizens' life. High trust in the state characterized by a decentralized and delegated political responsibility to authorities undermined citizens' critical vigilance of political decision-making. An economization of citizenship and depolitization of the economy [2] increasingly forms the Swedish culture into sacrificial citizenship.

The COVID-19 pandemic expresses an increased economization of political life associated with neoliberalism and reduced citizen participation in collective decisionmaking, which affect the organization of education. A relevant issue is the democratization [3] expanding popular participation in collective decision-making under intense social movements. It is interesting to reflect on recent and further changes in democracy and their impacts on policies to reduce social inequalities. For this reason, questions of interest are raised based on the observations of governments' discourses and consecrated literature without any pretensions of solving them. This study is limited why more investigations are required to enable more precise and more profound conclusions.

\section{References}

1. Brown, W.: In the Ruins of Neoliberalism: The Rise of Antidemocratic Politics in the West. Columbia University Press, New York (2019).

2. Brown, W.: Sacrificial Citizenship: Neoliberalism, Human Capital, and Austerity Politics. Constellations 23(1), 3-14 (2016).

3. Dahl, R. A.: Polyarchy: Participation and Opposition. Yale University Press (1973).

4. Brasil.: Base Nacional Comum Curricular. Ministério da Educação, Brasília (2018).

5. Peroni, V. M. V. (ed): Redefinições das fronteiras entre o público e o privado: implicações para a democratização da educação. Liber Livro, Brasília (2013).

6. Adrião. T. Dimensões e formas da privatização da educação no Brasil: caracterização a partir de mapeamento de produções nacionais e internacionais. Currículo sem Fronteiras 18(1), 8-28 (2018).

7. Dovemark, M. Kosunen, S. Kauko, Jaakko. Magnúsdóttir, B. Hansen, Petteri. Rasmussen, P.: Deregulation, privatisation and marketisation of Nordic comprehensive education: social changes reflected in schooling. Education Inquiry, 9(1), 122-141, (2018).

8. Johannesson, I. A., Lindblad, S., \& Simola, H.: An inevitable progress? Educational restructuring in Finland, Iceland, and Sweden at the turn of the millennium. Scandinavian Journal of Educational Research, 46(1), 325-339, (2002).

9. Wiborg, S.: Privatizing Education: Free School Policy in Sweden and England. Comparative Education Review, 59(3), 473-497, (2015)

10. Matos, C. C., Reis, M. E., Silva, S. P.: As Reverberações do Pensamento Liberal na Educação e sua Atualidade em Tempos de Pandemia. In: Diálogos Críticos, volume 3: EAD, Atividades remotas e o ensino doméstico: cadê a escola? Uchoa, A. M. da C. Sena, I. P. F. de S. Gonçalves, M. E. S. (eds). Editora Fi, Porto Alegre (2020).

11. Luna. 1 ano do corte de Weintraub: balbúrdia é o governo Bolsonaro, (2020), https://www.cartacapital.com.br/opiniao/1-ano-do-corte-de-weintraub-balburdia-e-ogoverno-bolsonaro/.

12. Raic, D. F. F; Cardoso, M. C.; Pereira, S. A. C. A universidade pública em cenários neoliberais e fascistas: barbúrdias de resistência em tempos de Covid-19. Revista Eletrônica de Educação, 14(1), 1-19, (2020). 
13. Mariz, Renata.: Ministro da Educação vai cortar $30 \%$ das verbas de todas as universidades federais, (2019), https://oglobo.globo.com/sociedade/educacao/ministro-daeducacao-vai-cortar-30-das-verbas-de-todas-as-universidades-federais-23634159

14. Rezende, C.: Weintraub: 'Não quero sociólogo, antropólogo e filósofo com meu dinheiro'. (2020), https://noticias.uol.com.br/colunas/constancarezende/2020/06/14/weintraub-nao-quero-sociologo-antropologo-e-filosofo-commeu-dinheiro.htm?utm_source=twitter\&utm_medium=social-media\&utm_content=geral\&utm campaign $=$ uol.

15. Burström, B.: What Is Happening in Sweden? International Journal of Health Services, 49(2), 204-211, (2019).

16. Sivesind, K. H. The Changing Roles of For-Profit and Nonprofit Welfare Provision in Norway, Sweden, and Denmark. In: Sivesind K., Saglie J. (eds). Promoting Active Citizenship, pp. 33-74. Palgrave Macmillan, London (2017).

17. Diderichsen, F.: How did Sweden Fail the Pandemic? International Journal of Health Services, 0(0), 1-6, (2021)

18. Meagher, G. Szebehely, M. The politics of profit in Swedish welfare services: Four decades of Social Democratic ambivalence. Critical Social Policy, 39(3), 455-476, (2019).

19. Dahlgren, G. Why public health services? Experiences from profit-driven health care reforms in Sweden. International Journal of Health Services, 44(1), 507-524, (2014).

20. Szebehely, M.: Internationella erfarenheter AV covid-19 i äldreboenden. Underlagsrapport till SOU, 80, (2020).

21. Ruis, A. R., Lee, S. B. Advances in quantitative ethnography. Springer Nature, Switzerland (2021).

22. Field, A. Discovering statistics using IBM SPSS statistics. Sage, London (2013).

23. Shaffer, D. W., Ruis, A. R. How we code. In: Ruis, A. R., \& Lee, S. B. (eds) Advances in quantitative ethnography, ICQE 2021: Communications in computer and Information science, vol. 1312, pp. 62-77. Springer Nature, Switzerland (2021). https://doi.org/10.1007/978-3-030-67788-6 5

24. Shaffer, D. W. Quantitative ethnography. Madison, Cathcart Press, (2017).

25. Marquart, C. L., Hinojosa, C., Swiecki, Z., Eagan, B., Shaffer, D. W. Epistemic Network Analysis (Version 1.7.0) [Software]. (2018), https://app.epistemicnetwork.org

26. Zörgö, S., Swiecki, Z., Ruis, A. R. Exploring the Effects of Segmentation on Semistructured Interview Data with Epistemic Network Analysis. In: Ruis, A. R., \& Lee, S. B. (eds) Advances in quantitative ethnography, ICQE 2021: Communications in computer and Information science, vol. 1312, pp. 78-90. Springer Nature, Switzerland (2021). https://doi.org/10.1007/978-3-030-67788-6 6

27. Hinojosa, C., Siebert-Evenstone, A.L., Eagan, B.R., Swiecki, Z., Gleicher, M., \& Marquart, C.: nCoder [Software] (2019). https://app.n-coder.org/

28. Shaffer, D. W., Collier, W., \& Ruis, A. R. A tutorial on epistemic network analysis: Analyzing the structure of connections in cognitive, social, and interaction data. Journal of Learning Analytics, 3(3), 9-45, (2016).

29. Arendt, H. The Promise of Politics. Knopf Doubleday Publishing Group, New York, (2009).

30. Bobbio, N. O futuro da democracia: uma defesa das regras do jogo. Paz e Terra, Rio de Janeiro, (1986).

31. Gramsci, A. Os Intelectuais e a Organização da Cultura. Civilização Brasileira, Rio de Janeiro, 1991.

32. Saviani, D. Escola e Democracia. Mercado de Letas, São Paulo, (1994).

33. Marshall, T. H. Part I: Citizenship and Social Class. In: Marshall, T., Bottomore, T. Citizenship and Social Class. London, Pluto Press, (1992). 
34. Silva, M. G. da S., Rodrigues, T. C. M. O Populismo de Direita no Brasil: Neoliberalismo e Autoritarismo no Governo Bolsonaro. Mediações 26(1), 86-107 (2021).

35. Martins, I. Weintraub pede volta às aulas em cidades com poucos casos de coronavírus. (2020), www.correiobraziliense.com.br/app/noticia/eu-estudante/ensino educacaoba$\underline{\text { sica/2020/04/16/interna-educacaobasica-2019,845316/weintraub-pede-volta-as-aulas- }}$ em-cidades-com-poucos-casos-de-coronavir.shtml

36. Hartmann, M. Boff, T. Aulas a distância aumentam fosso entre escolas públicas e particulares. (2020). https://gauchazh.clicrbs.com.br/educacao-e-emprego/noticia/2020/05/aulas-a-distancia-aumentam-fosso-entre-escolas-publicas-e-particulares-ckabhvddv0061015nlc5sjrpe.html

37. Roubicek, M. O que diz o primeiro dado de desemprego na pandemia. (2020), https://nexojornal.com.br/expresso/2020/04/30/O-que-diz-o-primeiro-dado-de-desemprego-na-pandemia.

38. Pasti, A. Bandeirs, O. Como o ensino a distância pode agravar as desigualdades agora. Nexo Jornal. (2020), https://www.nexojornal.com.br/ensaio/debate/2020/Como-o-ensino-a-distância-pode-agravar-as-desigualdades-agora

39. UFJF, Pesquisa da Andifes demonstra papel das universidades no combate à Covid-19. (2020) https://www2.ufjf.br/noticias/2020/05/11/pesquisa-da-andifes-demonstrapapel-as-universidades-no-combate-a-covid-19/

40. Ministério da Educação do Brasil. Nota Oficial de 16 de Março de 2020. (2020), http://portal.mec.gov.br/index.php?option=com_content\&view $=$ article\&id=86341:co mite-de-emergencia-do-mec-define-primeiras-acoes-contra-ocoronavirus \&catid $=33381 \&$ Itemid $=86$

41. BRASIL. Artigo 211 da Constituição da República Federativa do Brasil. (1988), http://www.senado.leg.br/atividade/const/con1988/con1988_04.02.2010/art_211_.asp

42. Brasil. Artigo 8 da Lei de Diretrizes e Bases da Educação Nacional. (1996), http://www.planalto.gov.br/ccivil 03/leis/19394.htm.

43. Todos pela Educação. $2^{\circ}$ relatório anual de acompanhamento do Educação Já. (2021), https://todospelaeducacao.org.br/wordpress/wp-content/uploads/2021/02/2o-Relatorio-Anual-de-Acompanhamento-do-Educacao-Ja final.pdf

44. Nygren, K.G., Olofsson, A.: Managing the covid-19 pandemic through individual responsibility: the consequences of a world risk society and enhanced ethopolitics. Journal of Risk Research 0(0), 1-5 (2020).

45. Beltrão, J. A., Teixeira, R. D., Taffarel, C. N. Z. Melo, F. D. A., Tranzilo, P. J. R. A Ofensiva dos Reformadores Empresariais da Educação em Tempos de Pandemia: o desastre social como oportunidade para avançar na privatização da Educação Básica. In: Diálogos Críticos, volume 3: EAD, Atividades remotas e o ensino doméstico: cadê a escola? Uchoa, A. M. da C. Sena, I. P. F. de S. Gonçalves, M. E. S. (eds). Editora Fi, Porto Alegre (2020).

46. Taffarel, C. N. Z., Nevez, M. L. C. Tendências da educação frente à correlação de forças na luta de classes: uma análise do governo Bolsonaro na perspectiva educacional. Estudos IAT 4(2), 310-329 (2019).

47. Franco, C de., Maranhão Filho, E. M. de A. A teocratização, privatização e militarização no governo Bolsonaro: perspectivas antidemocráticas e contrárias à educação. Mandrágoras 26(1), 203-224 (2020).

48. Strang, J.: Why do the Nordic countries react differently to the covid-19 crisis? (2020), https://nordics.info/show/artikel/the-nordic-countries-react-differently-to-the-covid19-crisis/ 